\title{
Effect of the Nematocides Nemagon and DD on Mineralization, Nitrification, Soil Microbial Population, and Soil Fertility Status of Two Tropical Soils ${ }^{1}$
}

\author{
H. D. Dubey, A. Riera, and R. L. Rodriguez ${ }^{2}$
}

\begin{abstract}
Nitrification was inhibited in an acid soil by $60 \mathrm{p} / \mathrm{m}$ or more of Nemagon; the $\mathrm{NH}_{4}{ }^{+}$ oxidizing bacteria being affected but not the Nitrobacter, as $\mathrm{NO}_{2}^{-}$accumulation was not observed. Nitrogen mineralization was not affected even at $20,000 \mathrm{p} / \mathrm{m}$ of Nemagon and an increase in available $\mathrm{P}, \mathrm{Mn}$, and a rise in $\mathrm{pH}$ occurred in both acid and alkaline soils. Extractable zinc increased in the acid soil.

DD was extremely toxic to the nitrifying bacteria; much more so than Nemagon. It inhibited $\mathrm{NH}_{4}{ }^{+}$oxidizing bacteria but not the Nitrobacter. Nitrogen mineralization was progressively depressed with increasing levels of $\mathrm{DD}$. It resulted in a decrease in $\mathrm{pH}$ and extractable P. Mn increased in both the acid and alkaline soils, whereas the effect on $\mathrm{Fe}$ and $\mathrm{Mg}$ were inconsistent. Bacteria, actinomycetes and fungi were suppressed drastically. At lower levels bacterial population was increased, indicating a possible role in detoxification of $\mathrm{DD}$.
\end{abstract}

\section{INTRODUCTION}

Soil fumigants are chemical pesticides widely employed to control nematodes. Many such chemicals are not entirely selective. Along with control of nematodes other microorganisms may be affected. This side effect may or may not be desirable from the point of view of crop production.

The nematocides Nemagon (1,2-dibromo-3-chloropropane) and DD (a 50-50 mixture of 1,3-dichloropropene and 1,2-dichloropropane) have been used extensively to control nematodes on pineapple in Puerto Rico. DD also has been used for this purpose in Hawaii, where soil side effects, such as restricted nitrification $(2,6)$ and altered availability of $\mathrm{Mn}, \mathrm{P}$, and $\mathrm{Fe}(5)$ have been reported.

Due to restricted nitrification, DD application results in increased soil ammonium. Pineapple plants, however, do not seem to be adversely affected as they use ammonium as well as nitrate forms of nitrogen (4). A DD application results in increased ammonium nutrition leading to faster growing, greener and more succulent plants. Crops able to utilize $\mathrm{NH}_{4}{ }^{+}-\mathrm{N}$ may grow normally, but such crops as tomato, celery and lettuce, which

1 Manuscript submitted to the Editorial Board May 22, 1974.

${ }^{2}$ Associate Soil Microbiologist, Chief Chemist, and Research Assistant, respectively, Agricultural Experiment Station, University of Puerto Rico, Mayagüez Campus, Rio Piedras, P.R. 
require $\mathrm{NO}_{3}^{-}-\mathrm{N}$, may be adversely affected if grown on fields treated previously with $\mathrm{DD}(1)$.

The effects of Nemagon on soils have not been published. The side effects of $\mathrm{DD}$ as noted in Hawaiian soils might not occur in Puerto Rico because of differences in climate and soil conditions.

The effects of Nemagon and DD on microbial populations, soil nitrogen mineralization, nitrification, and certain soil plant nutrients were therefore determined in two Puerto Rico soil types.

\section{MATERIALS AND METHODS}

Composite surface soil samples $(0-20 \mathrm{~cm})$ were collected from three sites: a) Bayamón sandy clay loam from a cultivated pineapple field, b) Bayamón sandy clay loam from a virgin site, and c) San Antón loam from a virgin site. The first two soils are acid and were collected from a pineapple growing area in Manatí. The San Antón loam, collected from the

TABLE 1.-Some characleristics of the soils used

\begin{tabular}{lcccccc}
\hline Soil type & $\mathrm{pH}$ & $\begin{array}{c}\text { Organic } \\
\text { matter }\end{array}$ & Sand & Silt & Clay & CEC . \\
\hline $\begin{array}{l}\text { Bayamón silty clay loam } \\
\quad \text { (cultivated) }\end{array}$ & 4.1 & 1.5 & 56 & 9 & 35 & 5.1 \\
$\begin{array}{l}\text { Bayamón silty clay loam } \\
\text { (virgin) }\end{array}$ & 4.3 & 1.9 & 61 & 12 & 27 & 6.7 \\
San Antón loam (virgin) & 7.7 & 5.1 & 42 & 33 & 25 & 34.1 \\
\hline
\end{tabular}

southern coast of the Island near Salinas, is alkaline and well known for its high fertility. Some of the important characteristics of these soils are given in table 1.

The soils were air-dried in a greenhouse and passed through a $2 \mathrm{~mm}$ sieve. Soil samples of $350 \mathrm{~g}$ each were adjusted first to near neutral $\mathrm{pH}$ by addition of $\mathrm{H}_{2} \mathrm{SO}_{4}$ or $\mathrm{Ca}(\mathrm{OH})_{2}$. To each soil sample, $3 \mathrm{ml}$ of soil inoculant from a known rapidly nitrifying soil was applied to ensure the presence of nitrifiers. The inoculant was obtained by shaking $500 \mathrm{~g}$ of soil with 1,000 $\mathrm{ml}$ of distilled water and filtering it through a filter paper. Half the samples received $100 \mathrm{p} / \mathrm{m} \mathrm{N}$ as $\left(\mathrm{NH}_{4}\right)_{2} \mathrm{SO}_{4}$ in $2 \mathrm{ml}$ of aqueous solution and the remainder served as controls. Upon drying, the samples were mixed thoroughly to distribute the additives uniformly throughout the soil.

Nemagon levels were 0,6 (the recommended field rate,) 60 and 600 $\mathrm{p} / \mathrm{m}$. DD levels were 0,200 (the recommended field rate), 2,000 and 20,000 $\mathrm{p} / \mathrm{m}$, on an active ingredient basis.

Nemagon was applied as follows: The $350 \mathrm{~g}$ soil samples, after $\mathrm{pH}$ adjustment and $\mathrm{N}$ treatment, were poured into glass bottles $17.8 \mathrm{~cm}$ tall and 
$5 \mathrm{~cm}$ in diameter. The necessary amount of Nemagon in $2 \mathrm{ml}$ distilled water solution was injected $15 \mathrm{~cm}$ deep in the center of the soil by a hypodermic syringe. Care was taken to inject the chemical at the above mentioned depth in order to simulate field treatment. As the needle was withdrawn enough distilled water was injected at three sites near the edge of the bottle so as to attain quickly field capacity. Water was injected using a $30 \mathrm{ml}$ Manopet syringe to which a needle $15 \mathrm{~cm}$ long was attached.

DD is insoluble in water. It thus was placed in bottles having only a 2.5 $\mathrm{cm}$ layer of soil, the remainder of the soil sample being poured in afterward. Water was injected as in Nemagon soils to attain field capacity.

After applying the treatments, the mouths of the bottles were covered with "Parafilm" which prevents moisture escape but permits gaseous exchange. The treatments were replicated three times and were incubated in the laboratory at $23 \pm 1^{\circ} \mathrm{C}$. A set of treatments were separated at fixed intervals for determination of $\mathrm{pH}$, mineral nitrogen, and other soil plant elements. After the soil was removed and air-dried for a day in the green house, a $50 \mathrm{~g}$ soil sample from each treatment was extracted with $250 \mathrm{ml}$ of $1.0 \mathrm{~N} \mathrm{KCl}$. Ammonium nitrogen in the extract was determined by distillation with $\mathrm{MgO}$ into 2 percent boric acid, followed by titration with standardized $\mathrm{HCl}$. Nitrite nitrogen was determined colorimetrically by the method of Prince (3). A second distillation with Devarda's alloy of the aliquot used earlier for $\mathrm{NH}_{4}{ }^{+}$determination gave the value for $\mathrm{NO}_{2}^{-}+$ $\mathrm{NO}_{3}^{-}$, from which $\mathrm{NO}_{3}^{-}$was obtained by subtracting the value for $\mathrm{NO}_{2}^{-}$. The $\mathrm{pH}$ was determined by glass electrodes in 1:1 soil: water suspension.

Calcium, magnesium and potassium were extracted from a $20 \mathrm{~g}$ soil sample with neutral ammonium acetate and analyzed in the Beckman flame photometer. Iron was extracted from a $20 \mathrm{~g}$ soil sample with neutral ammonium acetate. A $100 \mathrm{ml}$ aliquot was evaporated to dryness and digested with nitric and perchloric acids until a white residue was obtained. A Beckman DU spectrophotometer was used to make the analysis. Phosphorus was extracted from a $20 \mathrm{~g}$ soil sample by means of a sodium acetate solution of $\mathrm{pH} 4.8$ and analyzed in a Technicon Autoanalyzer. Zinc and manganese were extracted from a $20 \mathrm{~g}$ soil sample, with redistilled water and analyzed in a Jarell-Ash atomic absorption spectrophotometer.

Microbial population in the soil samples was determined by dilution plate technique. Soil bacteria and actinomycetes were grown on sodium albuminate agar medium and soil fungi were grown on Martin's Rose Bengal medium with streptomycin.

\section{RESULTS}

The virgin Bayamón soil was slightly higher in $\mathrm{pH}$, organic matter content, and cation exchange capacity than soil collected from a nearby pineapple field (table 1) as expected. San Antón soil, one of the most fertile 
soils of the Island, had an alkaline $\mathrm{pH}$ and was much higher in organic matter content and cation exchange capacity than the two acid soils.

Effects of the three rates of Nemagon on nitrification in the three soils are shown in table 2 . In the two untreated acid soils nitrification was almost complete in 8 weeks whereas in the untreated San Antón soil nitrification was completed in only 2 weeks. There was no significant difference in nitrification between the two acid soils, indicating that cropping or cultivation did not change their nitrifying capacity. When $6 \mathrm{p} / \mathrm{m}$ of Nemagon was applied to the Bayamón soil it strongly inhibited the nitrifying bacteria, as evidenced by a smaller amount of $\mathrm{NO}_{3}{ }^{-}-\mathrm{N}$ after 8 weeks. At 60

TABLE 2.-Effect of Nemagon $(p / m)$ on nitrification $\left(p / m\right.$ of $\left.\mathrm{NO}_{3}^{-}-N\right)$ of $100 \mathrm{p} / \mathrm{m}$ added $\mathrm{NH}_{4}^{+}-\mathrm{N}$

\begin{tabular}{lccccc}
\hline \multirow{2}{*}{ Soil type } & $\begin{array}{c}\text { Nemagon } \\
\text { added }\end{array}$ & \multicolumn{4}{c}{ NO-N formed after (weeks) } \\
\cline { 2 - 6 } & & 2 & 4 & 8 & 16 \\
\hline & 0 & & $P / m$ & & \\
Bayamón silty clay loam & 6 & 0 & 47.3 & 97.5 & 93.2 \\
(cultivated) & 60 & 0 & 2.9 & 26.7 & 85.5 \\
& 600 & 0 & 0 & 4.1 & 2.3 \\
Bayamón silty clay loam & 0 & 0 & 0 & 6.4 & 0 \\
(virgin) & 6 & 3.6 & 37.6 & 95.1 & 104.4 \\
& 60 & 0 & 6.4 & 34.8 & 75.2 \\
San Antón loam (virgin) & 600 & 0 & 0 & 0 & 56.6 \\
& 0 & 100.0 & 100.6 & 106.2 & 90.5 \\
& 6 & 88.7 & 91.9 & 99.6 & 92.4 \\
& 60 & 26.3 & 81.6 & 89.9 & 91.2 \\
& 600 & 0 & 18.1 & 22.5 & 17.2 \\
\hline
\end{tabular}

$\mathrm{p} / \mathrm{m}$ of Nemagon, no nitrification took place up to 16 weeks in the cultivated Bayamon soil. Nitrification had started by this time in the virgin soil, suggesting that the effect of the chemical was disappearing in this soil, thus permitting reestablishment and activation of nitrifying bacteria. In the San Antón soil the recommended field rate had hardly any effect on nitrification. Nemagon at $60 \mathrm{p} / \mathrm{m}$ inhibited nitrification significantly, and at $600 \mathrm{p} / \mathrm{m}$ very little nitrification occurred even after 16 weeks of incubation Apparently ammonium-oxidizing bacteria were affected but not the Nitrobacter, as no $\mathrm{NO}_{2}^{-}$accumulation was observed.

Nitrogen mineralization is the production by the heterogeneous microbial population of mineral nitrogen such as $\mathrm{NH}_{4}^{+}, \mathrm{NO}_{2}^{-}$, and $\mathrm{NO}_{3}^{-}$(which are easily available for plant use) from the essentially unavailable organic forms of nitrogen in the soil. The results (table 3) show, in general, that application of Nemagon did not affect nitrogen mineralization, thereby 
TABLE 3.-Effect of Nemagon on $N$ mineralization

\begin{tabular}{|c|c|c|c|}
\hline \multirow{2}{*}{ Soil type } & \multirow{2}{*}{ Nemagon added } & \multicolumn{2}{|c|}{$\begin{array}{l}\text { Mireral } N^{1} \text { formed after } \\
\text { (weeks) }\end{array}$} \\
\hline & & 2 & 16 \\
\hline & \multicolumn{3}{|c|}{$P / m$} \\
\hline \multirow{4}{*}{ Bayamón silty clay loam (cultivated) } & 0 & 118 & 135 \\
\hline & 6 & 116 & 146 \\
\hline & 60 & 108 & 122 \\
\hline & 600 & 124 & 102 \\
\hline \multirow{4}{*}{ Bayamón silty clay loam (virgin) } & 0 & 56 & 74 \\
\hline & 6 & 50 & 71 \\
\hline & 60 & 54 & 76 \\
\hline & 600 & 37 & 72 \\
\hline \multirow[t]{4}{*}{ San Antón loam (virgin) } & $\mathbf{0}$ & 113 & 149 \\
\hline & 6 & 105 & 139 \\
\hline & 60 & 117 & 141 \\
\hline & 600 & 102 & 135 \\
\hline
\end{tabular}

1 Mineral $\mathrm{N}=\mathrm{NH}_{4}^{+}+\mathrm{NO}_{2}^{-} ;$no $\mathrm{NO}_{2}^{-}$observed.

TABLE 4.-Effect of Nemagon on soil fertility status 8 weeks after application

\begin{tabular}{lrcccccc}
\hline Soil type & $\begin{array}{c}\text { Nemagon } \\
\text { added }\end{array}$ & $\mathbf{P}$ & $\mathrm{Mn}$ & $\mathrm{Zn}$ & $\mathrm{Mg}$ & $\mathrm{Fe}$ & $\mathrm{pH}$ \\
\hline & & & & $P / m$ & & & \\
Bayamón silty clay loam & 0 & 3.2 & 1 & 0.16 & 100 & 1 & 5.8 \\
(cultivated) & 6 & 4.0 & 1 & 0.18 & 100 & 1 & 5.9 \\
& 60 & 5.0 & 1 & 0.20 & 188 & 1 & 6.6 \\
Bayamón silty clay loam & 600 & 5.4 & 24 & 0.63 & 100 & 1 & 6.6 \\
(virgin) & 0 & 3.0 & trace & 0.12 & 138 & 1 & 6.1 \\
& 6 & 3.0 & trace & 0.25 & 113 & 1 & 6.0 \\
San Antón loam (virgin) & 60 & 3.0 & 1 & 0.13 & 113 & 1 & 6.2 \\
& 600 & 4.0 & 27 & 0.40 & 113 & 1 & 6.5 \\
& 0 & 56.6 & trace & 0.08 & 1031 & 2 & 7.1 \\
& 6 & 57.4 & trace & 0.13 & 1031 & 2 & 7.2 \\
& 60 & 61.6 & trace & 0.08 & 1044 & 2 & 7.1 \\
& 600 & 60.6 & 3 & 0.08 & 1050 & 2 & 7.2 \\
\hline
\end{tabular}

suggesting that nonspecific soil microbes are quite tolerant to this nematocide.

Increased Nemagon raised the $\mathrm{pH}$ and available phosphorus in each soil (table 4). A marked increase in available $\mathrm{Mn}$ was noted in the two acid soils receiving $600 \mathrm{p} / \mathrm{m}$ of Nemagon; but there was little increase in the San Antón soil. Similarly, a significant $\mathrm{Zn}$ increase was noticed in the acid soils receiving $600 \mathrm{p} / \mathrm{m}$ of Nemagon, but no such increase occurred in the San Antón soil. Magnesium and Fe levels remained unaffected by Nemagon.

Nitrification almost ceased for 8 weeks in all the soils after receiving 200 
JOURNAL OF AGRICULTURE OF UNIVERSITY OF PUERTO RICO

TABLE 5.-Effect of DD on nitrification of $100 \mathrm{p} / \mathrm{m}$ applied $\mathrm{NH}_{4}^{+}-\mathrm{N}$

\begin{tabular}{lrccc}
\hline \multirow{2}{*}{ Soil type } & DD added & \multicolumn{3}{c}{ NO-N formed after (weeks) } \\
\cline { 3 - 5 } & & 2 & 4 & 8 \\
\hline & & $P / m$ & & \\
Bayamón silty clay loam (cul- & 0 & 11.2 & 63.5 & 89.5 \\
tivated) & 200 & 2.8 & 1.4 & 0.4 \\
& 2,000 & 0 & 0 & 0 \\
Bayamón silty clay loam & 20,000 & 3.1 & 0 & 0 \\
(virgin) & 0 & 1.6 & 0 & 84.6 \\
& 200 & 0.9 & 0 & 4.3 \\
San Antón loam (virgin) & 2,000 & 1.6 & 0 & 0.3 \\
& 20,000 & 0 & 0 & 1.8 \\
& 0 & 79.4 & 88.1 & 93.0 \\
& 200 & 0 & 0 & 2.8 \\
& 2,000 & 0 & 0 & 2.8 \\
& 20,000 & 0 & 0 & 0 \\
\hline
\end{tabular}

Table 6.-Effect of $D D$ on $N$ mineralization

\begin{tabular}{lrrrr}
\hline \multirow{2}{*}{ Soil type } & DD added & \multicolumn{3}{c}{ Mineral N formed after (weeks) } \\
\cline { 3 - 5 } & & 2 & 4 & 8 \\
\hline \multirow{3}{*}{ Bayamón silty clay loam } & 0 & 50 & $P / m$ & \\
(cultivated) & 200 & 43 & 55 & 67 \\
& 2,000 & 34 & 40 & 61 \\
Bayamón silty clay loam & 20,000 & 34 & 41 & 42 \\
(virgin) & 0 & 45 & 68 & 67 \\
& 200 & 44 & 64 & 71 \\
San Antón loam (virgin) & 2,000 & 21 & 36 & 41 \\
& 20,000 & 23 & 32 & 33 \\
& 0 & 78 & 106 & 128 \\
& 200 & 74 & 109 & 124 \\
& 2,000 & 67 & 88 & 105 \\
& 20,000 & 66 & 75 & 79 \\
\hline
\end{tabular}

${ }^{2}$ Mineral $\mathrm{N}=\mathrm{NH}_{4}^{+}+\mathrm{NO}_{3}^{-}$; no $\mathrm{NO}_{2}^{-}$observed.

$\mathrm{p} / \mathrm{m}$ DD (table 5). During the same period in the untreated acid soils nitrification had progressed 85 to 90 percent, but in the alkaline soil it was completed in 2 weeks. The ammonium oxidizing bacteria appeared to be inhibited but not the Nitrobacter as no accumulation of $\mathrm{NO}_{2}-\mathrm{N}$ occurred.

Whereas Nemagon had no effect on $\mathrm{N}$ mineralization, DD progressively inhibited the process (table 6).

Research conducted in this laboratory has consistently shown that San Antón soil has a very high nitrifying and detoxifying capacity. DD has been the most toxic of the pesticides tested in this laboratory to nitrifying 
TABLE 7.-Changes in soil microbial population 8 wecks after application of $D D$

\begin{tabular}{|c|c|c|c|c|}
\hline Soil Type & DD added & Bacteria & Actinomycetes & Fungi \\
\hline & $P / m$ & $\times 100,000$ & $\times 100,000$ & $\times 1,000$ \\
\hline \multirow{4}{*}{$\begin{array}{l}\text { Bayamón silty clay loam } \\
\text { (cultivated) }\end{array}$} & 0 & 134 & 6 & 33 \\
\hline & 200 & 248 & 18 & 3 \\
\hline & 2,000 & 5 & 0 & 0 \\
\hline & 20,000 & 0 & 0 & 0 \\
\hline \multirow{4}{*}{$\begin{array}{l}\text { Bayamón silty clay loam } \\
\text { (virgin) }\end{array}$} & 0 & 82 & 98 & 49 \\
\hline & 200 & 57 & 43 & 3 \\
\hline & 2,000 & 1 & 1 & 0 \\
\hline & 20,000 & 1 & 0 & 0 \\
\hline \multirow{4}{*}{ San Antón loam (virgin) } & 0 & 116 & 30 & 50 \\
\hline & 200 & 240 & 31 & 25 \\
\hline & 2,000 & 204 & 0 & 0 \\
\hline & 20,000 & 0 & 0 & 0 \\
\hline
\end{tabular}

TABLE 8.-Effect of $D D$ on soil fertility status

\begin{tabular}{lrrrrrrr}
\hline Soil type & DD added & pH & P & Mn & Fe & Mg & $\mathrm{Zn}$ \\
\hline & \multicolumn{1}{c}{$P / m$} & & & \multicolumn{2}{c}{$P / m$} & & \\
Bayamón silty clay loam & 0 & 6.4 & 6 & 0 & 0.52 & 50 & 0 \\
(cultivated) & 200 & 6.7 & 6 & 0 & 1.04 & 38 & trace \\
& 2,000 & 6.3 & 5 & 0 & 0.50 & 38 & trace \\
& 20,000 & 5.5 & 2 & 24 & 0.97 & 38 & trace \\
Bayamón silty clay loam & 0 & 6.4 & 7 & 0 & 1.50 & 100 & 0 \\
(virgin) & 200 & 6.7 & 9 & 0 & 0.95 & 100 & 0 \\
& 2,000 & 6.4 & 8 & 18 & 1.50 & 138 & 0 \\
San Antón loam (virgin) & 20,000 & 5.8 & 4 & 240 & 2.00 & 200 & trace \\
& 0 & 7.2 & 64 & 0 & 1.1 & 988 & 0 \\
& 200 & 7.2 & 64 & 0 & 0.6 & 1000 & 0 \\
& 2,000 & 7.1 & 65 & 0 & 0.3 & 1088 & 0 \\
& 20,000 & 7.0 & 59 & 61 & 0.5 & 1100 & 0 \\
\hline
\end{tabular}

bacteria and heterogenous microbial population such as $\mathrm{N}$ mineralizers. It was thus considered essential to investigate its effects in detail on the different classes of soil microbes. The results of microbial count recorded 8 weeks after DD application to soils are given in table 7. The DD eliminated all types of microbes in every soil when applied at the $2000 \mathrm{p} / \mathrm{m}$ level. This effect was more drastic in acid than alkaline soils. At the $200 \mathrm{p} / \mathrm{m}$ rate the bacterial population increased indicating that bacteria may be using this chemical in their metabolism, thus instrumental in its detoxification. Bacteria were suppressed at rates higher than $200 \mathrm{p} / \mathrm{m}$, however.

Analyses of soil fertility elements in soil samples 8 weeks following DD application showed that $\mathrm{pH}$ and available $\mathrm{P}$ decreased with high rates of $\mathrm{DD}$ (table 8). This is in contrast to the findings of Smith (5), who reported in- 
creased $\mathrm{pH}$ and available $\mathrm{P}$ following $\mathrm{DD}$ application. At high levels $\mathrm{DD}$ increased available $\mathrm{Mn}$.

\section{RESUMEN}

A dos suelos ácidos (arcilla arenosa Bayamón) y a uno alcalino (San Antón lómico) se les aplicaron los nematocidas Nemagon y DD, el primero a concentraciones de 0,6 , 60 y $600 \mathrm{p} / \mathrm{m}$ y el segundo a las de $0,200,2,000$ y $20,000 \mathrm{p} / \mathrm{m}$. Muestras de los suelos tratados se incubaron en el laboratorio en condiciones de humedad equivalentes a las de campo, a una temperatura de $23^{\circ} \pm 1^{\circ} \mathrm{C}$. Se analizaron las muestras a distintos intervalos para detectar la presencia de nitrógeno mineral y otros elementos nutritivos y además determinar el efecto sobre la mineralización del nitrógeno, la nitrificación del $\mathrm{NH}_{4}+-\mathrm{N}$ añadido, el estado de fertilidad del suelo y la población microbiana.

Aplicado a razón de $60 \mathrm{p} / \mathrm{m}$ en el suelo ácido, el Nemagon inhibió la nitrificación. Este efecto fue aumentando progresivamente a medida que subia el nivel de Nemagon. Las bacterias oxidantes del amonio se afectaron, pero no así las Nitrobacter, ya que no se observó acumulación de $\mathrm{NO}_{2}^{-}$. Tampoco hubo efecto alguno sobre la mineralización del nitrógeno. La aplicación de Nemagon aumentó el contenido en $\mathbf{P}$ y $\mathbf{M n}$ asimilables y también subí el pH. En los suelos ácidos también aumentó el contenido en $\mathrm{Zn}$ extractible.

El DD produjo efectos extremadamente tóxicos sobre las bacterias nitrificantes, mucho más que los que tuvo el Nemagon. Restringió a las bacterias oxidantes del amonio, pero no así a las Nitrobacter. Suprimí, en proporcibn a la cantidad usada, la mineralización del nitrógeno. La aplicación de DD resultó en descenso en $\mathrm{pH}$, así como en el contenido de P extractible. En todos los suelos el nivel de Mn aumentó, pero con respecto a $\mathrm{Fe}$ y $\mathrm{Mg}$ los resultados fueron inconsistentes. DD suprimió drásticamente a las bacterias, los actinomicetes y los hongos del suelo. Aplicado a menores concentraciones, el DD produjo un aumento en la población bacteriana, lo cual indica, posiblemente, que las bacterias juegan un papel importante en la desintoxicación del DD.

\section{LITERATURE CITED}

1. Davidson, J. H., and Thiegs, B. J., Fumigation side effects, Biokemia (DOW), No. 13: 15-7, 1966.

2. Koike, H., The effects of fumigants on nitrate production in soil, Soil Sci. Soc. Amer. Proc. 25 (3) : 204-6, 1961.

3. Prince, A. L., Determination of total nitrogen, ammonia, and nitrites in soils, Soil Sci. 59: 47-52, 1945.

4. Sideris, C. P., Krauss, B. H., and Young, H. Y., Assimilation of ammonium and nitrate by pineapple plants grown in nutrient solutions and its effects on nitrogenous and carbohydrate constituents, Plant Physiol. 13: 489-537, 1938.

5. Smith, D. H., Effects of fumigants on the soil status and plent uptake of certain elements, Soil Sci. Soc. Amer. Proc. 27 (5) : 538-41, 1963.

6. Tam, R. K., The comparative effects of a 50-50 mixture of 1:3 dichloropropene and 1:2 dichloropropane (D-D mixture) and of chloropicrin on nitrification in soil and on the growth of the pineapple plant, Soil Sci. 59: 191-205, 1945. 